\title{
Organization Theory and Public Administration
}

Tom Christensen

\section{Summary}

Organizational theories could be classified into three types - structural, cultural and myth, where the first belongs to the logic of consequence and the latter two to the logic of appropriateness. The theories focus the importance of formal structural design, cultural traditions and appropriateness, and the use of myths and symbols, respectively. They are, in combination with more political science theories, used to analyze decision-making in public organizations, whether related to agenda-setting, policy-making, negotiations, regulation, implementation, public reforms, etc.

Keywords: Organization theory, public organization, instrumental-structural perspective, cultural perspective, myth perspective, logic of consequence, logic of appropriateness, decision-making.

\section{Introduction}

Organization theory encompasses a wide variety of theories that have been used to analyze decision-making in public and private organizations (Scott and Davis 2006). The aim here is to select some main strands of the vast variety of organization theories and show their relevance for analyzing decisions in public organizations. The theories used is partly originating in organizational sociology or social constructivism, but many, particular the instrumental-structural ones, emanate from business schools and used on analyzing private organizations (Christensen et al. 2007). This latter aspect means that the politicaladministrative context will be discussed and also how more general political-democratic theories may be used to make organization theory more relevant for studying public organizations. This also done to stress that organization theories are not primarily used as technical instruments of analyses, but as lens to interpret both political and administrative features of decision-making. Such theories has been used extensively to study primarily such areas as public reforms (Christensen and Lægreid 2007, 20111; Greve et al. 2016;

Hammerschmid et al. 2016; Pollitt and Bouckaert 2017), but also crisis management (Boin et al. 2014), globalization of higher education (Meyer et al. 2006) and reputation management (Gavrila and Ramirez 2019; Wæraas and Maor 2015)

The selection made of the organization theories discussed is based in two main approaches to public administration studies (March and Olsen 1989). The first is a logic of 
consequence, focusing on means-end oriented or instrumental rationality, and more specifically on the theory of bounded rationality by Simon (1957), or what is called 'administrative man'. Instrumental economic theories, like synthesized by Knott and Hammond (2014), will not be discussed, mainly because they are not typical organization theories. The differences between these two instrumental theories, is that the first one is focusing on the importance of organizational rationality and the importance of formal structure, while the second one more emphasize a priori goals, full information and individual freedom of choice, deemphasizing structural and cultural frames (March 1994).

The second main approach is based on a logic of appropriateness, which is connected to two varieties of what is called institutional theories (Christensen et al. 2007). The first is the cultural theory of Selznick (1957), which make the important distinction between organization and institution, where institution alludes to the importance of informal norms and values, the significance of path-dependency and local task environment, meaning local stake-holders the institution is particular dependent of (Scott 2013). The second version is often called neo-institutionalism or here myth perspective, where the basis is a combination of social constructivism and certain parts of organizational sociology, and the focus is on the institutional environment (Meyer and Rowan 1977). This implies t,he macro environment of an institutional nature consisting of a set of myths or symbols that put pressure on a public organization to adapt to what is seen as acceptable or reasonable ways of organizing and acting. This means that a public organization is embedded in a broader set of cultural and social constraints. Institutional theories based in economic theory will not be discussed (Peters 2011), because they are more economical-rational than institutional theories.

The two sets of approaches presented, with their more specific theories or perspectives attached, represent different sets of contexts that explain in different ways how the central dependent variable, the decision-making behavior of public actors, is shaped in different ways. They have been very important in one type of rather dominant studies in Public Administration, i.e. studies of public reforms (Van de Walle and Groeneveld 2016). Decision-making behavior may allude to two different types of processes (Egeberg 2014). The administrative policy process, whereby actors in formal political-administrative organization decide on how to organize the formal apparatus, the recruitment of personnel and their physical design and location. Further, the process whereby public actors decide based on the results from the first process. The focus could be more on the effects internally in the public apparatus, for example whether the design of the organization has resulted in changes in the pattern of influence among central actors. Or, the emphasis could be on the 
wider societal effect such as on the social conditions of citizens or specific user/client groups, often called outcomes.

In the following, some reflections on an organization theory for public administration is elaborate. Then three main strands of organization theory will be presented - instrumental, cultural and symbolic. Then the importance of blending organization theory with democracy theories and other theories from political science, tis discussed, to grasp what is typical public. This is followed by a discussion on how one can use the organization theories to analyze different elements, processes and effects related to public decision-making.

\section{An Organization Theory for Public Administration}

\section{What Is Typical for Analyzing Public Administration?}

Based on the fact that some of the organization theories, in particular the instrumental ones, historically are coming out of American business schools (Augier and March 2011), one have to pose the question of whether such theories are suitable for understanding and analyzing public organizations in general and public administration specifically. Allison (1983) ones wrote a book chapter with the title 'Public and private managers: are they fundamentally alike in all unimportant respects?' His arguments were basically three. Public interests differ from private interests, and therefore public leaders and organizations/institutions from private ones, in that they have to balance a much wider and complex set of considerations, including a variety of formal and informal norms and values. Constitutional norms, broader democratic considerations, like participation, transparency, impartiality, equal treatment, predictability/stability, public welfare norms, etc. are all typical public considerations (Olsen 1992).

Second, public organizations and their leaders are in representative democracies primarily accountable to citizens and voters and not owners, shareholders or other stakeholders. What Olsen (1992) labels the 'parliamentary chain' is important; voters delegate through elections authority to the elected and executive leaders that have an administrative apparatus to their disposal to fulfill popular based goals for the development of the society. This means that to grasp the role of public administration, one has to put it into a political and administrative context.

Lastly, public organizations differ from private ones in that they basically don't operate on competitive markets. Despite increasing commercialization and marketization of 
the public sector, not to mention the blurring of the borders of public and private organizations (Self 2000), this basically still holds true

\section{Combining Organization Theory and Political-Democratic Theory}

According to the characteristics of what is typical for public organizations, it's rather evident that organization theory has to be combined with public administration research based in political science. March (1997) argues that this originally was typical in US, but that gradually disappeared from the 1960s, while this combination reappeared in the Scandinavian tradition, whether based in bounded rationality or the emerging institutional theories (Christensen and Lægreid 2013; Czarniawska-Joerges and Sevon 2003). The Scandinavian tradition differs from the American one that it's less technical, more oriented towards political contexts, more process oriented, often using qualitative methods and more focused on how ideas are emerging, translated and diffused (Christensen and Lægreid 2018). Thoenig (2003) also points to that this tradition differ from the continental law tradition and is closer to Anglo-Saxon behavioralism.

Studies combining organization theory and political science-based studies of public administration, have traditionally focused on governance capacity, but have increasingly also been interested in governance legitimacy (Christensen, Lægreid and Rykkja 2018).

Governance capacity alludes to the core argument that organization matters, whether related to structure or resources, but that is a political matter not a technical one. The focus is on how formal public organizations like ministries, agencies, state-owned enterprises, regional and local administrations, etc. are organized and reorganized, and with what effects. The more complex the world, the more complex the public apparatus and the more challenges of 'wicked issues' reaching across levels and sectors (cf. Rittel and Webber 1973). Governance legitimacy deals with the support from the citizens towards the governments' way of organizing and conducting the public activities. This support could, according to Easton (1965), be 'diffuse' meaning of a general and system-supporting nature, or more specifically supporting some institutions and some actors.

There is a dynamic between between governance capacity and legitimacy. If a political-administrative system is well organized and functioning well regarding public services, the citizens support could be strong, which further will give the system more 
resources to improve and leaders more leeway. Fukuyama's (2014) argument on the importance of the quality of the public apparatus is reflecting this tendency, and the same is the Quality of Government research effort in Sweden (Holmberg and Rothstein 2014). Or, the contrary, if the governance legitimacy is under pressure, like one see all over the world, related to a combination of popular discontent with social or other societal conditions, the governance capacity could be strained and challenged.

\section{Organization Theory Strands}

\section{An Instrumental-Structural Theory}

This type of theory, associated with the logic of consequence (March 1994), started out from the basic assumption that organizing was important for how people acted in formal organizations. In several seminal studies of private organizations the focus were on how working processes could be more effective and efficient. An important example of those were the studies of Frederick W.Taylor (1911) who is seen as the father of Scientific Management. Parallel to his works there emerged a similar type of studies, with Henri Fayol and James D. Mooney as the main early proponents, which put more explicit emphasis on leadership and the significance of structural design of formal organization. This direction, later called Administrative Management, was brought into studies of public organizations, in his case the federal administration in US, by Luther H. Gulick, that discussed in much more systematic way the importance of formal design of organizations.

Gulick (1937) had the central assumption that there were a connection between public goals, the way the formal political-administrative structure was designed and the content of public policy and therefore also the effects on the larger society. This meant that based on public goals leaders could chose a selected set of alternative structures, but never just one, that potentially could fulfill these goals. He further differentiated his theory and said it build on two basic dimension of organizing, namely specialization and coordination, and their dynamic relationship. Specialization for him meant how public organizations were specialized vertically in different leadership levels and horizontally in separate units. He divided the principles of horizontal organizing into four: a purpose principle (f.ex. functional sectors), a process principle (f.ex. different processes or expertise), a clientele principle (f.ex. user/client groups) and a geographical principle. 
Concerning coordination, Gulick basically divided those into coordination through formal organization, which he focused the most, and through ideas. Coordination through formal organization could be of two types. Hierarchical coordination, or the command-andcontrol principle, focused on how leaders could control through using their exclusive leadership decision-making authority in different ways, where the allocation of tasks and autonomy between hierarchical levels played an important part. Further, horizontal or collegial coordination, where actors on the same level, for example leaders, could discuss and decide. Cyert and March (1963) later on elaborated on the latter by saying that solutions in collegial coordination could be the result of voting with winners/losers; sounding-out and negotiation processes ending in compromises (Olsen 1972); or sequential attention to goals and quasi-solution of conflicts, meaning 'log-rolling' and actors getting their say at different points in time, a solution prioritizing short-term effectiveness but having problems with longterm consistency..

Egeberg (2014) is one of the researchers most systematically following up Gulick's basic thoughts over time and in different contexts, both national and international (Egeberg and Trondal 2009). He has worked systematically based on what he has called an instrumental model, where he has elaborated on the basic thoughts of Gulick and also added factors related to personnel/demography and physical structure as independent factors influencing decision-making behavior. Egeberg has also more systematically worked on what is called 'two-hattedness', meaning situations where an actor has divided obligations and roles, for example to national and international administrations, like EU, and looked at the importance of primary and secondary affiliations (Egeberg and Trondal 2018).

Simon (1946) lauched a very strong attack on Gulick, basically indicating that his principles were unscientific and that one could quite easily propose rather different or opposing principles. Hammond (1990), in a systematic discussion of their controversy, basically says that Simon was too heavy-handed and partly wrong in his critique, and that Gulick's and Simon's works have a lot in common. Following this latter view, one can say that Simon and March elaborated on Gulick's theory in at least two ways. First, in particular in his book 'Administrative Behavior' (1957) Simon systematically discussed the importance of how the formal structure in organizations is channeling and influencing the way actors are thinking and acting. Adding to this, March and Simon (1958) discussed the limitations of an organizational-psychological nature that actors face when selecting decision-making premises and making decisions. This meant that actors in formal organizations have limitations on their cognitive capacity and attention. Combining these two seminal books, it's 
also evident how rationality limitations partially could be modified by systematic structural design.

Central insights from both Gulick and Simon is reflected in another seminar book, 'The Semi-sovereign People' by E.E. Schattschneider. He formulated the deep insight that 'organization is mobilization of bias'. This mean that when leaders, for example of public organizations, decide to organize new units or restructure old ones, certain actors, problems and solutions are systematically organized in, while others are organized out and less attended to. This is also one of the main reasons for that large reorganizations and reforms often are controversial (Pollitt and Bouckaert 2017). The 'winners', that are well organized in and represented, would like to keep their influence, while 'losers' would like to be more included through reforms and changes.

The garbage can model, made famous in an article by Cohen, March and Olsen from 1972, and followed up in subsequent works (Cohen and March 1974; March and Olsen 1976), has diverse rational elements. The model focusing on how the theory on bounded rationality is modified, i.e. it's called 'organized anarchy', which means that the organizational element is still there. The more modified the organization rationality is in the model, the more the individual rationality is coming into the forefront. This is a theme that is central in Allison's (1971) book on the Cuban Missile crisis in the early 1960s. One of the models used in his analysis is the 'organization process model', which imply that when coordination fails in a big public organizations, it could be because of individual or 'local rationality' which may lead to irrationality of the system, sector or organization as a whole.

March and Olsen (1976) stress that every decision-making process has some basic elements in fours streams of actors, problems, solutions and decision-making opportunities, which on the one extreme could be pretty uncoupled, like in the garbage can model, to being rather coupled, like in the basic bounded rational theory. Kingdon (1984) in his seminal work on what has been called multiple-streams, build on March and Olsen and says that decisionmaking processes has three streams - problems, politics and policies. In his modified version of the garbage can model he emphasize more of the organizing element and stress that the streams can be organized or coupled in systematic ways, for example through the actions of policy entrepreneurs, to influence not only agenda-setting but also more generally public decision-making (cf. Aberbach and Christensen, 2001).

\section{A Organization-Cultural Theory - Institutionalization and Path Dependency}


A core argument in Selznick's (1957) organizational-cultural theory, belonging to the logic of appropriateness approach, is that it's an important distinction between the concepts of organization, alluding to instrumental processes and formal structures, an institution, which is related to informal norms and values and more an organic or natural analogy (Scott and Davis 2006). Further it's argued that the process of institutionalization is characterized by that formal organizations, like public administrative bodies, are mutually adapting to internal and external pressure, which is adding informal norms and values to the formal ones. So, an institutionalized organizations is an institution. As is evident from Selznick's (1949) seminal study of Tennessee Valley Authority, internal pressure relates to what internal actors are bringing into the organization and how they interact, while external pressure relates to external stake-holders in what is often labeled local or task environment (Thompson 1967).

The institutionalization processes are resulting in institutional features that are unique, because the combination of internal and external pressure differs from organization to organization and the resulting informal features will therefore differ. While instrumental theory focuses on what organizations $d o$, cultural theory relates to what they are or represent (Scott and Davis, 2006). This is related to what norms and values they overall represent, like focusing on environmental or human rights values; to what groups they focus on, whether citizens overall or special user groups; to what kind of tasks they are working with.

Selznick (1957) emphasizes that leaders in organizations with strong institutional features score high on what he labels 'statemanship'. That means that they take 'critical decisions' that decides the core institutional norms and values and are different from routine decisions. These critical decisions relate to having visions for the development of the institution, embody the central informal norms and values through their leadership, recruit organization members based on their commitments, socialize and 'indoctrinate' members, having appropriate representational systems, solve conflicts, etc.

Krasner (1988) discusses different dimensions of institutionalization. One central dimension is vertical depth, which means to what extent institutional factors are influencing the thoughts and actions of organization members. Another way to look at this is to ask what the relative importance of the organization-cultural identity is compared to the formal ones, or social identities outside the institution. Are the organization members well socialized into or have internalized the cultural norms and values? The other dimension is horizontal width, meaning how well integrated an institution is horizontally regarding the culture. Do organization member feel that they are in the 'same boat', that activities and cultural features in other parts of the institution is relevant and important for them? Will organization 
members, physically dispersed, share the same basic informal norms and values (Kaufman 1960)? The two dimensions taken together means that an organization with strong institutional features is one scoring high on both vertical depth and horizontal width.

A central concept in this type of cultural theory is path dependency. This means that the informal norms and values that is typical for the period and context when it was established will be very important for the path further chosen (Krasner 1988). So, 'roots will determine routes'. This means for example that a public organizations established after the WW2 would be rather different from one establish during the student revolution in the late 1960s or one in the aftermath of the global economic crisis around 2008. The reasoning behind this is that when the leaders and members of the organization gradually is developing unique informal norms and values, it will be increasingly difficult to choose other paths, because too much is invested in the one followed. In the words of Pierson (2000), it's the mechanism of 'increasing returns' that is working. The advantage of strong, historically based values is that they will be important guidelines for thoughts and actions, while the disadvantage is that an institutions and its members could be 'stuck in a generation or era' if not informal norms and values are continuously changed, at least to a certain extent with changing preconditions. A strong cultural tradition or path could also have importance for how attempts of change is handled. Brunsson and Olsen (1993) point to that lack of cultural compatibility might obstruct or modify public reforms, for example the fit between old public management norms and values and New Public Management reform efforts (Christensen and Lægreid 2001).

March (1994) explains the meaning of another central concept given this type of institutional theory, i.e. the logic of appropriateness. There are two processes related to this concept. First, historically, there is a process of institutionalization where it's developed which informal norms and values that are the appropriate ones to think and act according to. These values could be rational norms, like the ones discussed under the instrumental theory, but they could also be connected to other institutional logics, for example value-rational. Second, it's the process whereby actors in the institution should act according to what historically has been developed as appropriate norms and values. This is called a matching process. The actor has to match three types of factors: actors must know and understand their institutional identity, meaning understand the process outlines above, they must decide what kind of situation they're in, for example a routine or crisis one, and know about possible decision rules and premises. So, in reality this means that the same perceptions of the cultural identity and situations will lead actors to use the same decision rules and premises, while 
cultural heterogeneity and disagreement may lead to a variety of actions and decisions (Christensen and Røvik 1999).

The so-called historical institutionalism, represented by important works by Steinmo, Thelen and Longstreth (1992) and Thelen (1999) is an important elaboration of Selznick's cultural theory. In newer works, like Streeck and Thelen (2005) this elaboration is more explicit having element from rational theory. They make a distinction between change processes, that can be either incremental or abrupt/sudden, and the result of the change process that can either represent continuity or discontinuity. The first combination of the two dimensions represent the traditional path dependency theory, meaning combination of incremental change and continuity. On the other extreme, one have breakdown and discontinuity, which is represented by the theories on critical junctures and disjointed equilibriums, resulting in a new path (Baumgartner and Jones 1993; Collier and Collier 2002; Mahoney 2000). A third combination is sudden change and continuity, which by some is seen as cultural 'backsliding', that may show the strength of a system's traditional cultural values. A last combination is gradual transformation, representing substantial discontinuity as a result of incremental change, meaning that many small and gradual changes eventually, through a cumulative process, is resulting in major changes.

Streeck and Thelen (2005) further elaborate on the category gradual transformation and divide it into the following types: Substitution, meaning that traditional cultural norms and values are unstable and weak, and have few actors that is still supporting them, which pave the way for new institutional logics and behavior. Substitution could also be a result of 'invation' of new cultural norms. The next type is 'layering and sedimentation' and means that actors add new cultural norms and values that is living side-by-side with the old ones that often gradually will be wholly or partly be deinstitutionalized or pushed aside. Third, flow represent institutions that, for different reasons have problems with adapting and maintain traditional norms that will less and less be actively in use. This is a process of atrophy. The next type is basic change in type or form, meaning that new actors decide on new tasks and norms for old structures, as a result of new external constraints. An the last type is institutional exhaustion, where represent gradual institutional breakdown, but not change, meaning that the institution is have expanded too much, running out of resources or is characterized by old age.

\section{A Theory on Myths and Symbols}


This theory, also part of the logic of appropriate approach, which core development is connected to some central scholars of organization-sociology at Stanford, is similar to the cultural theory in the way that it's basically a historical-evolutionary or natural system theory (Scott and Davis 2006). It's, however, different in the way that while cultural theory is about variety and uniqueness, this theory is about similarity among institutions. This can be seen in the way institutionalization is defined. According to Meyer and Rowan (1977) institutionalization is a process whereby individual accept a common definition of the social reality, which gives the potential for similarity within and between institutions, and potential of standardization in thinking, action and organizational forms. There are three phases in the process of institutionalization. First, externalization means that institutions and individuals act and interact, and there are established patterns of informal norms and values within organizational/institutional frames. Second, objectivization means that actors interpret actions, norms and values as external realities, decoupled from themselves. This gives a potential for deterministic adaptations, i.e. adaptation is seen as imperative (TINA - there is no alternative) and appropriate. Third, the objective world is influencing the single actor through internalization and lead to that they can act according to a set of governing principles that are seen as external and on the macro level, which simplify the selection decision premises.

Meyer and Rowan (1977) divides the environment of organizations into two parts, i.e. the technical environment, related to instrumental processes, and the institutional environment. The institutional environment has a non-action character. It consists of models of thought, types of knowledge, professions, organizational forms, systems, tasks, services and products that are taken for granted that as appropriate or acceptable, and is the source of the development of myths (Scott and Davis 2006). Institutionalized rationalized myth are defined as when common interpretations and prevailing norms and values have common prevalence, a 'rule-like' character and is not scrutinized much regarding effects (March 1994). Myths are seen as rather simple or general principles - 'rules of thumb' - that can give meaning and order to a complex world, adding to structural mechanism and constraints.

The standard interpretation of the spreading of myths is that they spread through fast imitation, which is saving resources, through a strong deterministic pressure from the macro environment. Myths may first spread within countries, sectors, organizations, professions, programs and practices, and then between them, like is seen with modern reform myths (Christensen and Lægreid 2007). The results of the imitation processes are isomorphism, i.e. institutions that at the outset are different, seems to be similar in form. There are two types of 
isomorphy, competition-related and institutional. The institutional is often divided into three types (DiMaggio and Powell 1983): the coercive type, resulting from strong pressure from organizations in the environment an institution is dependent of, like a superior ministry; mimetic, driven by ambiguity and insecurity in goal, means, technology and environment and where change agents like consulting firms can sell cheap standard solutions; and normative, which alludes to how norms and values are spreading in and between professions

When myths are entering organizations, what is happening? The standard interpretation is that the myths become part of the formal structure that is shown to the environment, so-called 'window-dressing', and the result is formal structural isomorphism (March 1994). This alludes to the classical distinction made by Gofmann (1957) between front-stage and back-stage. This means that the institution is pretending that what the structure actors in the environment see is the one influencing actions internally, while in reality it's the underlying 'old' structure that is important in this respect. The new structure represent a 'social construction of reality' (Berger and Luckmann 1967).

Institutions incorporate myths because they think it will increase their legitimacy, so they will be seen as modern and rational (Brunsson 1989). They would like to shape and reflect symbolic congruence with the environment. They will get support and resources because of symbols, but not necessarily actions related to them, and they often are characterized by 'double-talk', i.e. they talk in one way and decide and act in another. There are different ways to decouple myths and action (Brunsson 1989). Chronological, meaning that instrumental and institutional considerations are attended to at different points in time (Cyert and March 1963; March and Olsen 1989). Further, myths could more easily be used in issues that are complex and ambiguous, for example 'wicked issues', reaching across levels and sectors/institutions. Third, an institution could relate to specific stake-holders in the environment that are speaking the same symbolic language. And lastly, specialize certain parts of own institution on myths and other on instrumental actions, whether the politicians more easily speak in symbolic terms and bureaucrats in instrumental, or certain units have tasks where the preconditions are better for myths.

An extended version of this neo-institutional theory starts from the idea that 'globalization' promotes formalized associations or organizations as cultural meanings or myths (Drori et al. 2003; Meyer, Drori and Hwang 2006: 25-26). Dominant social and cultural attitudes towards both public and private organizations are framed globally rather than nationally or locally and they value formal and rationalized arrangements (Meyer 2009). Globalization is mainly a cultural and social process, a culturally 'imagined community', and 
contributes to weakening or deconstructing certain structures, such as nation states and classical bureaucracies, and supporting the emergence of new, rationalized ones (Anderson 1983). New forms of identities develop and become culturally dominant. It is widely believed that the formal organization as a globalized phenomenon is objectively preferable and dominant. Globalization is seen as a two-tiered process, whereby internationality and transnationality are enhanced by the diffusion of models around the world, but at the same time the global aspect is consolidated through the creation of a world society. This is reflected in areas like higher education/ universities/science (Christensen et al. 2018; Drori et al 2003, Meyer and Schofer 2006), management/standards (Brunsson and Jacobsson 2002), regulation (Djelic and Sahlin-Andersson 2006), etc.

\section{The Dynamic Between the Three Theories}

So, what is the potential dynamics between the three theories concerning explaining public decision-making? A public leadership with relatively strong power and authority may heavily influence the development of a public organization, like in Selznick's (1957) cultural theory, i.e. the culture is supporting the effects of formal norms and values on decisions. But, strong cultures, like for example professional cultures, may also strongly influence the formal structure that could be changed as a result of this. A further option may be that structure and culture is mutually reinforcing each other, like Christensen and Peters (1999) show in a comparative study of governance in Norway and US.

There are obvious instrumental elements in the myth theory. According to Brunsson (1989), a public leadership may overall be important in shaping and spreading myths and symbols. They may also have different strategies for handling myths, like creating a systematic image, understand and use different organizational fashions, deemphasize internal coordination, use a myth-related organizational language, stress intentions to act and isolate the leadership from the production system. In his instrumental take on the myth theory, Røvik (2002) talks about partial myths coming from different organizational fields, institutional standards and multi-standard organizations. And, on the contrary, myths may influence instrumental processes and limit the options for the leaders, because their own symbolic narratives are pushed aside by counter-myths. But, there could also be a pressure, both from leaders and ordinary organization members that myths are put into practice, meaning the basic decoupling is not possible to maintain (Christensen et al. 2007). 
A strong organization culture with a long tradition and path connected may use special symbols to underline the core of the culture. But, changing cultural paths could also be made easier with the systematic use of symbols (Kingdon 1984). Myths and symbols, originating from strong external pressure, may also heavily influence and eventually change cultural norms and values, not to mention formal structural arrangements. Røvik (2002) stresses that myths may travel longer and faster if they have certain features like being socially authorized by power centers; theorized and universialized, so they become abstract and decontextualized and travel more easily; made into products, so they can be sold on a global market; seen as part of the Zeitgeist; harmonized to bridge the interest of many actors; dramatized, to attract attention; and individualized, like seen in the use of symbols in higher education institutions (Gavrila and Ramirez 2019).

\section{Important Research Questions and Study Areas According to the Organization}

\section{Theories.}

\section{The Instrumental-Structural Theory}

The main empirical focus according to this theory is the formal structure of public organizations in general or more specifically public administrative organizations. By the formal structure or organization one think of the principles of specializing and coordinating, whether intra- or inter-organizational (Egeberg 2014; Gulick 1937; Simon 1957). These principles are non-personal, in the way that they are not connected to personal characteristics of the individuals who are occupying public roles. Public organizations comes in many forms or shapes, from narrow and deep hierarchies with a lot of power to the top leadership; through wide and narrow hierarchies with delegated authority; to loosely coupled organizations, etc. (cf. Mintzberg 1989).

Focusing on the formal structure of public organizations leads to three basic questions (Egeberg 2014): What is characterizing the process whereby the formal structure is established or changed/reorganized? Furtheron, what is characterizing the way the public organizations are structured? And last, what are the effects of organizing public organizations one way or the other? All three questions relate, according to March and Olsen (1976), to two basic aspects or building block of organization. One is the structure of actors or the decision structure, the other is the structure of problems or solution or the access structure. If the decision and access structures are strictly organized, meaning that few actors with fixed 
goals, problems and solutions are dominating decision-making process, there is relatively easy to predict decision content and policies. If, on the other hand, the decision and access structures are less strictly organized, it's more important which actors are activated and how problems and solutions are defined by different actors and over time. This means that the results of decision-making processes are less easy to predict.

Going back to the process whereby the formal structure of public organization is established or changed, it can be organized in different ways (March and Olsen 1976). One way is the basic hierarchical way, meaning that the top leadership dominate both concerning direct participation and what should be the goals, problems and solutions of the process. One of the challenges with this are the capacity and attention of leaders (Cohen and March 1974; March and Simon 1968). Another is the potential lack of legitimacy when the number of actors involved is limited (Mosher 1967).

Another way of organizing the decision process is specialized, which means attending to the expertise of actors, whether they are leaders or more typical professional actors. Allison (1971) labels this ‘bureaucratic politics' model, while in March and Olsen's (1983) this is called the negotiation model or 'Realpolitik'. The advantage with this way, with its wider selection of actors, is that it's creating more support and legitimacy (Mosher 1967). The disadvantage is more that it's often produces compromises that could be rather loose and ambiguous. Decisions could be reached among actors in a winning coalition, in negotiation between a majority and a minority of actors, or through an agreement of fulfilling different interests at different points in time (Cyert and March 1963).

The third way is the unspecialized way, meaning a near lack of structural frames guiding decision-making process. This is what is typical for the garbage can model, which has what one call strong temporal features (Cohen, March and Olsen 1972). The metaphor alludes to that decision-making processes are characterized by fluctuations in the streams of actors, problems, solutions and choice opportunities, and also changing couplings of these streams, resulting in unpredictable and varied content of the decisions. Such processes could either just happen, of different reasons, or be the result of purposeful design, to increase innovation, and historical examples of this is universities and other research organizations (Cohen and March 1974; March and Olsen 1976).

Based on the instrumental-structural theory, one could also study the effects of formal structures, even though that is less focused compared to processes (Egeberg 2014). As alluded to, one of the basic insights from Gulick (1937) is that there is a rather tight connection between goals, public organizing and effects, even though combining different 
ways of specializing and coordinating may more lead to a selection of structural alternatives and their effects than a belief in 'one size first all' (jf. Hood and Jackson 1991).

What kind of effects are typical for public administration studies? Studies may be of changing patterns of influence. Are there, for example, clear and intended effects of reorganizing the formal structure on which actors that have decision influence in reality? Further, what are the effects of reforms and reorganizations on the content of policies and definitions of problems and solutions? Both these questions could be either answered through comparative and intensive case studies, but more common has been comprehensive national and cross-national studies, based on interviews and surveys that is covering the perceptions of civil servants or other public actors. Lastly, there could also be studies more generally on efficiency, effectiveness and quality, which is all internally directed, or studies of societal effects, like social cohesion and social inequality, like Hammerschmid et al. (2016) comparative study of the effects of NPM-related reforms in 17 countries, showing a lot of variety in top civil servants' perceptions.

So, what kind of studies on change processes and formal governmental structures could be connected to this type of theory? Overall, an instrumental-structural perspective is the most common analytical background for many types of studies in Public Administration, like studies of public reforms. One example is the very comprehensive study of Pollitt and Bouckaert (2017) of public sector reforms, both New Public Management (NPM) and postNPM, where 12 countries and the European Commission is compared over time. Christensen and Lægreid (2001 and 2007) is comparing public sector reforms, in particular NPM, in the Australia, New Zealand and the Nordic countries, while Christensen and Lægreid (2011) is broadening the geographical catch and has chapters from authors covering countries all around the world. Greve et al (2016) cover rather extensively modern reform processes in the Nordic countries. The broad COCOPS projects, covering 17 European countries, has public reforms as one of its foci (Hammerschmid et al. 2016).

There are some basic insights one can get from these studies. One is that the decision structure, or the structure of participants, are often rather fixed and predictable in reform processes and more often of a hierarchical than negotiational nature (Christensen and Lægreid 2001 and 2007). Second, even though central reform templates may create convergence among countries, their differences in constitutional and formal structural factors in the political-administrative systems participate in explaining divergence in reform solutions. 
The Norwegian Administrative Survey, which started in the mid 1970s and has been repeated every $10^{\text {th }}$ year since then, is typical for a type of deep national study on perceived effects of organizing and reorganizing (Christensen et al. 2018). It shows that there are both stability and changes occurring over 40 years in the central civil service. It's stability in role perceptions, perception of influence and contacts, but large changes in gender compositions, with women increasing their share a lot, and higher education background, , with the strong increase of the share of social scientists

Based on the COCOPS survey, that has a special focus on top civil servants, Greve et al. (2016) analysed the perceptions of civil servants in the Nordic countries and Hammerschmid et al. (2016) in many more European countries. The most comprehensive study so far is based in the COST Action and COBRA Survey and covers 30 countries around the world (Verhoest et al. 2010 and 2012). It's empirically focused on government agencies and studied both the process of agencification, what is characterizing the agencies in a comparative perspective and what the effects of these types of reforms are.

\section{The Cultural-Institutional Theory}

There are a different set of questions for public administration studies that are emerging from cultural-institutional theory. It's crucial to look into administrative traditions for public organizations. What are some of the main trends of administrative traditions around the world, like Raadschelders (1998) has studied in his comprehensive book? How are these traditions changing over time, converging or diverging? More specifically, what characterized the context concerning cultural norms and values when a specific set of public institutions or single institutions were established (cf. Pollitt 2013)? To what degree and in what ways are the historical paths stable or changing over time? What actors are the main carriers of the traditions and are there disagreements and tension among professional groups? There are different sources to answer such questions, whether it's historical accounts from historians or political scientists in the form of administrative histories, biographies about or from politicians or administrative leaders. Or, it can be studies of the development of professions or studies of demography over time (Christensen and Lægreid 2009).

Further, what is the importance of historical paths for early $21^{\text {st }}$ century decisionmaking processes? Are the paths informing and influencing overall the decisions, through being embedded in formal structures, dominant norms and practices, or are there only actors with a long tenure that is carrying the traditions? Data for such studies are often a 
combination of actors being able to make personal accounts of the important of the historical path, but also perceptions of actors whether they are aware of and using certain traditional informal norms and values in their decision-making. One example of such studies is Christensen et al. (2018) survey-based study that shows that central cultural norms for role enactment in Norwegian ministries and agencies are rather stable over time.

One can also study whether reform and reorganization processes are compatible with the existing informal norms and values that are important in public administration (Brunsson and Olsen 1993). There are many options that might occur. One is that the reorganization represent culturally incompatible norms and values. Most often that will result in cultural resistance and that the proposed changes are bounced back and not implemented, like one see with attempts to implement New Public Management in countries that have basic collective and egalitarian norms (Christensen and Lægreid 2001). But the political or administrative leadership can so strongly advocate the reorganizations or reforms, through entrepreneuships, that the institution start on another cultural path (Kingdon, 1984). Another option is that reforms are partly implemented, where the parts that are most compatible will be implemented, like when Nordic countries more easily implement performance management systems, but are more reluctant towards marketization and privatization (Christensen and Lægreid 2007). A last option is that change impulses are so culturally compatible that they are easily implemented.

Eleanor Westney (1987) in her seminal book Imitation and Innovation, uses elements from cultural theory combined with rational elements, like one see in elaborations of historical institutionalism (Pierson, 2004; Streeck and Thelen, 2005). She analyses how Japan in the Meiji period (1859-1912) systematically imitated the West, mostly Western Europe and US, to change a number of its public and private organizations. She says that the imitation had elements of what could be called 'rational shopping', but the focus here is on the cultural preconditions of imitation and the cultural compatibility question. The Japanese delegations that went abroad had to understand the cultural context of the countries they imitated, but that was a big challenge, because of lack of expertise, differences from their own culture and the evolution of and changes within the cultural solutions they imitated. When Japan imitated for example European systems such as postal services, police organizations, and newspaper businesses, they only imitated parts of the underlying culture, because they did not culturally grasp the full picture of their imitation. When they returned home to adapt the imitated solutions, with their distorted picture of the cultural context in the West, they had problems of determining which part of their own culture should be adapted or 
kept. So, this is a book about cultural understanding of other cultures and cultural compatibility related to imitation (cf. Brunsson and Olsen 1993).

\section{Symbol and Myth Theory Used on Change in Public Organizations}

The first crucial question using this theory empirically is to establish that there are in fact symbols and myths that are existing and relevant for decision-making processes in public organizations, including change processes. So, how do one go about as a researcher to find that out? One can analyze the content or expressions related to decisions, like traditional media, social media, informal and formal public reports and documents, minutes from debates in elected bodies, etc. One can also focus on data that more specifically present the images of public organizations, like the analyses of their websites (Christensen et al. 2019; Wæraas and Maor 2015). The basic effort here is to reveal whether the content of the texts more or less explicit use certain ways of expression or terms that are alluding to value-based symbols or myths that are part of some kind of meaning-making process, directed either to external stake-holders or to internal actors (March 1994).

Another important question is what are the driving forces behind the existence and use of myths and symbols, i.e. both their establishment and spreading (DiMaggio and Powell 1983). Taking a broad global view, one would look for global cultural, social, technological and economical forces that may lead to symbols and myths being spread and important, in general or related to crises like terrorist or security crises, global economy crisis, environmental crises, etc.(Boin et al. 2014; Lodge and Wegrich 2012) But, one could also, based on a more instrumental version of this theory (Brunsson 1989; Røvik 2002), focus on how national and international actors, like national authorities and international organizations systematically are spreading myths (Czerniawska and Sevon 1996; Sahlin-Andersson 2001). Are there typical certification processes going on, behind the spreading, supported by these actors, or more typical negotiation processes? How important are professional global and national networks for this spreading of myths? How about the role of large commercial actors, like global or national consulting or auditing firms for the spreading of myths (Christensen and Lægreid 2003)?

A third question relates to the effects of symbols and myths in public decisionmaking. As presented, the myth theory in its standard version is stating that myths don't have instrumental effects, i.e. public institutions and their leaders will manage to keep apart the myths, which are images and 'window-dressing', on the one hand, and structures and other 
instrumental factors that are in fact influencing decisions, on the other (Brunsson 1989; Meyer and Rowan 1977). One simple way to do this is to compare what central public actors are saying and what they are doing (March 1986). So, if there seems to be 'double-talk', one can infer that one has to do with myths and symbols that are not influencing practice, meaning 'loose coupling' (March and Olsen 1976). But, there are several challenges with this. Talk could be so ambiguous that there is not easy to tell what should be the connecting action. If talk is not resulting in action, the reason could be lack of knowledge or capacity, or changing constraints and preconditions for decisions that are difficult to handle (Christensen et al. 2007).

All this could lead to another source, i.e. the actors could be asked whether they on purpose used myths/symbols and how they see them connected to action. One challenge with this is of course whether the actors would tell the truth or pretend or after-rationalize, something that could be modified by triangulation, meaning having several data points that could balance each other. Studies using this method seems to show some different types of mechanisms (Christensen and Lægreid 2001 and 2007). Actors may tell that they had intentions of talking in one way and act in another, to get legitimacy through both, as stated by Brunsson (1989). Or, they may tell that they on purpose used the symbols to make the actual instrumental process looks more rational, i.e. the symbols work in a supportive way. Or, they had the intention to balance talk and action, but it ended up in more talk than action because of instrumental difficulties (March and Olsen 1983). Or, there were actors, like leaders, that eventually decided to try to operationalize and implement some of the myths and symbols, because that could build their careers, or the pressure from actors lower down in the organization became so strong that they had to deliver more on some of the talk (Christensen and Lægreid 2003).

Regarding the studies related to the broader version of the myth theory, they are mainly focused on different ways to find out whether formalized myths have been spreading globally, through different types of data (Meyer, Drori and Hwang 2006; Meyer 2009).

\section{Conclusion}

Three strands of organization theory has been presented (Christensen et al. 2007); the instrumental-structural theory is based on the logic of consequence, while the cultural and myth theories are based on the logic of appropriateness (March 1994). An instrumental perspective digs into the importance of the formal structure of an organization, to influence models of thought and actions, but also the importance of controlling the processes of 
designing and changing organizations (Simon 1957). An organization-cultural perspective digs more into the importance of informal norms and values, cultural uniqueness, path dependency and cultural compatibility related to changes (Selznick 1957). A symbolic or myth perspective take as a point of departure the importance of institutional macro environments, broad social and cultural processes, the shaping and spreading of myths, isomorphism and 'double-talk' (Brunssson 1989; Meyer and Rowan 1977).

It's important to show how these theories needs to be converted and adapted to studies of public organization. One way to do this is to connect them to studies of democracies and more typical political science studies, to show the importance of the political-administrative context public leaders are operating in (Christensen et al. 2007). Change processes in public organizations are political-administrative in nature and not technical. When politicaladministrative leaders try to further public goals, they can be helped by changing cultures and instrumentally using symbols. But, there are often also dynamics implying cultural resistance and counter-myths, potentially undermining such implementation (Patashnik 2014).

It's been it was discussed what type of research questions could be posed based on the theories and which types of studies are typical for them. Based on the instrumental perspective, questions of design, control, rational thinking, etc. are often posed, and the empirical data are often public laws, rules, organigrams, public reports, debates in public bodies, etc. (Egeberg 2012) The cultural perspective looks more ta informal norms and values, relative to the formal ones, and is connected to studies that focuses professional norms and values, cultural compatibility and path dependency, based on another type of data, often historical accounts about or by public leaders (Pierson 2004). The myth or symbolic perspective focuses more on question of the importance of symbols for the working of public organizations and digs into use of narratives, media and social media, and other informal types of sources (March 1994).

Based on the organization theories presented, there are several interesting potential research agendas emerging. First, inter-disciplinary studies is growing fast, like related to life science or environmental studies (Sauve, Bernard and Sloan, 2016). Second, many studies of accountability and reputation management are emerging, using elements from the theories presented (Busuioc and Lodge, 2016). A third possible research avenue is opened up by (Peci and Sobral 2011), where extensive data from the users of public services and actors exposed to regulation, taken from diverse social media, are compared with the perceptions of the civil servants and politicians. 


\section{References}

The titles marked with $(\mathrm{E})$ is essential reading.

Aberbach, J. D. and T. Christensen (2001). Radical reform in New Zealand: crisis, windows of opportunities, and rational actors. Public Administration, 79 (2): 404-422.

(E)Allison, G.T. (1971). Essence of Decision (Boston: Little, Brown).

Allison,G.T. (1983). Public and Private Mangers: Are They Fundamentally Alike in All Unimportant Respects? In J.L. Perry \& K.L. Kraemer (Eds.), Public Management. Public and Private Perspectives. Palo Alto, CA.: Mayfield Publishing.

Anderson, B. (1983). Imagined Communities. London: Verso.

Augier, M. \& J.G.March (2011). The roots, rituals, and rhetorics of change: North American business schools after the second World War. Stanford: Stanford University Press.

Baumgartner, F., \& Jones, B. (1993). Agendas and Instability in American Politics. Chicago: University of Chicago Press.

Boin, A., Ekengren, M. \& Rhinard,M. (2014). Transboundary Crisis Governance. In J. Sperling (Ed.), Handbook of Governance and Security (pp. 307-323). Cheltenham, UK: Edward Elgar.

(E)Brunsson, N. (1989). The Organization of Hypocrisy. Talk, Decisions and Actions in Organizations. Chichester: Wiley.

Brunsson, N. \& Olsen, J.P. (1993). The Reforming Organization. London and New York: Routledge.

Busuioc, M.E. \& Lodge, M. (2016). The reputational basis of public accountability. Governance, 29 (2), 247-263.

Christensen, T., \& P. Lægreid (Eds.) (2001). New Public Management. The Transformation of Ideas and Practice (Aldershot: Ashgate).

Christensen, T., \& Lægreid, P. (2003). Administrative Reform Policy: The Challenges of Turning Symbols into Practice. Public Organization Review: A Global Journal, 3: 3 27.

Christensen, T., \& P. Lægreid (Eds.) (2007).Transcending New Public Management Aldershot: Ashgate.

(E)Christensen, T. \& Lægreid, P.(Eds.) (2011). The Ashgate Research Companion to New Public Management. Surrey, UK and Burlington, VT, USA: Ashgate. 
Christensen, T., \& Lægreid, P. (2013). Scancor and Norwegian Public Administration Research Development, Nordiske Organisasjonsstudier, 15, 91-110.

Christensen, T., Egeberg, M., Lægreid, P. \& Trondal, J. (2018). Sentralforvaltningen. Stabilitet og endring gjennom 40 år (The central civil service. Stability and change during forty years). Oslo: Universitetsforlaget.

Christensen,T., Å.Gornitzka \& F.O.Ramirez (eds.)(2019). Universities as Agencies. Reputation and Professionalization. London and New York: Palgrave Macmillan.Christensen, T., \& Peters, B.G. (1999). Structure, Culture and Governance. A Comparison of Norway and The United States. Lanham: Rowman \& Littlefield.

(E)Christensen,T., Lægreid, P., Roness, P.G. \& Røvik, K.A. (2007). Organization Theory and the Public Sector. London: Routledge.

(E)Cohen, M.D., March, J.G., \& Olsen, J.P. (1972). A Garbage Can Model of Organizational Choice. Administrative Science Quarterly, 17 (1):1-25.

Cohen, M.D., \& March, J.G. (1974). Leadership and Ambiguity: The American College President. Boston, MA: Harvard Business School Press.

Cyert, R.M., \& March, J.G. (1963). A Behavioral Theory of the Firm. Englewood Cliffs, N.J.: Prentice-Hall.

Czarniawska, B., \& Sevón, G. (Eds.) (1996). Translating Organizational Change. Berlin: De Gruyter.

Czarniawska, B., \& Sevon, G. (2003). The Northern Lights. Organization Theory in Scandinavia. Lund: Liber.

Dahl, R.A., \& C.E. Lindblom (1953). Politics, Economics, and Welfare. New York: Harper \& Row.

(E)DiMaggio, P.K., \& W.W. Powell (1983). The Iron Cage Revisited: Institutional Isomorphism and Collective Rationality in Organizational Fields, American Sociological Review, 48, 147-160.

Drori, G.S., Meyer,J.W., Ramirez, F.O. \& Schofer, E. (2003). Science in the Modern World Polity. Institutionalization and Globalization. Stanford: Stanford University Press.

Easton, D. 1965. A Systems Analysis of Political Life. New York: Wiley.

(E)Egeberg, M. (2014). How Bureaucratic Structure Matters: An Organizational Perspective. In B.G. Peters \& J. Pierre (Eds.), Handbook of Public Administration. London: Sage. 
Egeberg, M., \& Trondal, J. (2009). National Agencies in the European Administrative Space: Government Driven, Commission Driven or Networked?, Public Administration, 84, 779-90.

(E)Egeberg, M., \& Trondal, J. (2018). An organizational approach to public governance. Oxford: Oxford University Press.

Fukuyama. F. (2014). Political Order and Political Decay. New York: Macmillan.

Gavrila, S.G., \& Ramirez, F.O. (2019). Reputation Management Revisited: U.S. Universities Presenting Themselves Online. In T.Christensen, Å.Gornitzka \& F.O.Ramirez (eds.)(2019). Universities as Agencies. Reputation and Professionalization. London and New York: Palgrave Macmillan.

Goffman, E. (1990). The Presentation of Self in Everyday Life. New York: Penguin.

Greve, C., Lægreid, P. \& Rykkja, L.H. (2016). Nordic Administrative Reforms. Lessons for Public Management. London: Palgrave Macmillan.

(E)Gulick, L. (1937). Notes on the Theory of Organizations. With Special Reference to Government. In L. Gulick \& L. Urwin (Eds.), Papers on the Science of Administration (New York: A. M. Kelley).

Hammerschmid, G., Van de Walle, S., Andrews, R. \& Bezes, P. (Eds.). Public Administration Reforms in Europe. The View from the Top. Cheltenham, UK and Northampton, MA, USA: Edward Elgar.

(E)Hammond, T.H. (1990). In Defence of Luther Gulick's 'Notes on the Theory of Organizations'. Public Administration, 68(Summer), 143-173.

Hood, C., \& Jackson, M. (1991). Administrative Argument. Aldershot: Dartmouth.

Holmberg, S., \& Rothstein, B. (Eds.)(2014). Good Government: The Relevance of Political Science. Cheltenham: Edward Elgar.

(E)Kingdon, J. (1984). Agendas, Alternatives, and Public Policies. Boston: Little, Brown. Knott, J. \& T.H.Hammond (2014). Formal theory and public administration. In B.G.Peter \& J.Pierre (eds.), The SAGE Handbook of Public Administration. London: Sage. 2.edition.

Krasner, S.D. (1988). Sovereignty. An Institutional Perspective, Comparative Political Studies, 21, 66-94.

Lodge, M. \& Wegrich, K. (2012). Conclusion: Executive Politics in Changing Climate. In M.Lodge \& K.Wegrich (Eds.), Executive Politics in Times of Crisis. (pp.284-296). London: Palgrave Macmillan. 
Mahoney, J. (2000). Path dependency in historical sociology. Theory and Society, 29: 507548.

(E)March, J.G. (1994). A Primer in Decision Making. New York: Free Press.

March, J.G. (1997). Administrative Practice, Organizational Theory, and Political Philosophy: Ruminations on the Reflections of John M. Gauss, PS Political Science, 30, 689-98.

March, J.G., \& Olsen, J.P. (1976). Ambiguity and Choice in Organizations. Bergen: Universitetsforlaget.

March, J.G., \& Olsen, J.P. (1983). Organizing Political Life. What Administrative Reorganization Tells Us About Government, American Political Science Review, 77, 281-97.

(E)March, J.G., \& Olsen, J.P. (1989). Rediscovering Institutions. New York: The Free Press.

(E)March, J.G., \& Simon, H.A. (1958). Organizations. New York: John Wiley \& Sons.

(E)Meyer, J.W., \& Rowan, B. (1977). Institutionalized Organizations: Formal Structure as Myth and Ceremony, American Journal of Sociology, 83, 340-63.

Meyer, J.W. (2009). Reflections: Institutional Theory and World Society. In G. Krucken \& G.S. Drori (Eds.), World Society. The Writings of John W. Meyer. Oxford: Oxford University Press.

Meyer, J.W., Drori, G.S., \& Hwang, H. (2006). World Society and the Proliferation of Formal Organization. In J.W. Meyer, G.S. Drori \& H. Hwang (Eds.) Globalization and Organization. World Society and Organizational Change. Oxford: Oxford University Press.

Mintzberg, H. (1989). The Structuring of Organizations. In D.Asch and C.Bowman (Eds.) Readings in Strategic Management. Palgrave, London

Mosher, F. (Ed.) (1967). Governmental Reorganizations. Indianapolis: Bobbs-Merrill Company.

Olsen, J.P. (1972). Voting, 'Sounding Out' and the Governance of Modern Organizations. Acta Sociologica, 15(3), 267-283.

Olsen, J.P. (1992). Analyzing Institutional Dynamics, Staatswissenschaften und Staatspraxis, $2,247-71$.

(E)Peters, B.G. (2011). Institutional Theory in Political Science: The "New Institutionalism", 3rd edn. London and New York: Continuum. 
Patashnik, E.M. (2014). Reforms at Risk. What Happens after Major Policy Changes are Enacted. Princeton and Oxford: Princeton University Press.

Peci, A. \& Sobral, F. (2011). Regulatory impact assessment: How political and organizational forces influence its diffusion in a developing country. Regulation \& Governance 5:204-20.

Pierson, P. (2004). Politics in Time: History, Institutions and Social Analysis. Princeton: Princeton University Press.

Pollitt, C. (Ed.) (2013). Context in Public Policy and Management. The Missing Link? Cheltenham: Edward Elgar.

(E)Pollitt, C., \& Bouckaert, G. (2017). Public Management Reform: A Comparative Analysis. Oxford: Oxford University Press. 4th edition.

Raadschelders, J.C.N. (1998). Handbook of Administrative History. New Brunswick and London: Transactions Publishers.

Rittel, H.W.J., \& Webber, M.M. (1973). Dilemmas in a General Theory of Planning, Policy Sciences, 4, 155-69.

Røvik, K.A. (2002). The Secrets of the Winners: Management Ideas That Flow. I K. SahlinAndersson \& L. Engwall (Eds.), The Expansion of Management KnowledgeCarriers, Flows and Sources. Stanford, CA: Stanford University Press.

Sahlin-Andersson, K. (2001). National, International and Transnational Construction of New Public Management. In T. Christensen \& P. Lægreid (Eds.), New Public Management. The Transformation of Ideas and Practice. Aldershot: Ashgate.

Sauve, S., Bernard, S. \& Sloan, P. (2016). Environmetal sciences, sustainable development and circular economy: Alternative concepts for trans-disciplinary research. Envionmental Development 17, 48-56.

Schattschneider, E.E. (1960). The Semisovereign People. Illinois. The Dryden Press.

(E)Scott, W.R. (2013) Institutions and Organizations, 4nd edn. Thousand Oaks: Sage.

(E)Scott, W.R., \& Davis, C. (2006). Organizations and Organizing: Rational, Natural and Open Systems Perspectives, 6th rev. edn. NJ: Prentice Hall.

Self, P. (2000) Rolling Back the State. Economic Dogma \& Political Choice. New York: St. Martin's Press.

Selznick, P. (1949). TVA and the Grass Roots. Berkeley: University of California Press. 
(E)Selznick, P. (1957). Leadership in Administration. New York: Harper \& Row.

(E)Simon, H.A. (1946). The Proverbs of Administration. Public Administration Review, 6(1), 54-67.

(E)Simon, H.A. (1957). Administrative Behaviour. New York: Macmillan.

Steinmo,S.,Thelen,K., \& Longstreth, F. (1992) Structuring Politics: Historical Institutionalism in Comparative Analysis. Cambridge: Cambridge University Press.

Streeck, W., \& Thelen, K. (2005). Beyond Continuity. Oxford: Oxford University Press.

Taylor, F.W. (1911). The Principles of Scientific Management. New York: Norton.

Thelen, K. (1999). Historical Institutionalism in Comparative Politics. Annual Review of Political Science, 2, 369-404.

J.-C.(2003). Institutional Theories and Public Institutions: Traditions and Appropriateness. In B.G. Peters \& J. Pierre (Eds.), Handbook of Public Administration (London: Sage).

J. Thompson (1967). Organizations in Action. New York: McGraw-Hill.

Verhoest, K., Roness,P.G., Verschuere, B., Rubecksen, K., \& MacCarthaigh, M. (2010). Autonomy and Control of State Agencies. Comparing States and Agencies.Basingstoke: Palgrave Macmillan.

Verhoest,K., Van Thiel, S., Bouckaert, G., \& Lægreid, P. (Eds.) (2012). Government Agencies. Practices and Lessons from 30 Countries. London: Palgrave Macmillan.

Walle,S.van de \& Groeneveld, S. (Eds.)(2016). Theory and Practice of Public Sector Reform. New York and London: Routledge.

Westney, D.E. (1987). Imitation and Innovation. Cambridge, MA: Harvard University Press. Wilson, J.Q. (1989). Bureaucracy. What Government Agencies Do and Why They Do it . New York: Basic Books.

Wæraas, A., \& Maor, M. (Eds.)(2015).Organizational Reputation in the Public Sector. London: Routledge. 